\title{
Haemochromatosis and aldosterone deficiency presenting with Yersinia pseudotuberculosis septicaemia
}

\author{
S.P. Conway ${ }^{1}$, N. Dudley ${ }^{2}$, P. Sheridan ${ }^{2}$ and H. Ross ${ }^{3}$
}

Departments of ${ }^{1}$ Infectious Diseases and ${ }^{2}$ Medicine and ${ }^{3}$ Regional Public Health Laboratory, Seacroft Hospital, York Road, Leeds LS14 6UH, UK.

\begin{abstract}
Summary: A 50 year old man presented with a pyrexial illness following a holiday abroad. Yersinia pseudotuberculosis was isolated from blood culture. Response to appropriate antibiotic therapy was prompt and complete, but full recovery was complicated by an episode of hyperkalaemia, hyponatraemia and the passing of large volumes of dilute urine. Three years previously he had developed diabetes mellitus and hypogonadotrophic hypogonadism. Investigation on recovery showed underlying haemochromatosis and aldosterone deficiency.
\end{abstract}

\section{Introduction}

Yersinia pseudotuberculosis is a Gram-negative coccobacillus ubiquitous within the animal kingdom. Human infection can occur by ingestion of food contaminated by animal excreta, drinking infected milk or water, or by direct contact with an infected animal. ${ }^{1}$ In man it produces two distinct clinical entities, acute mesenteric adenitis and septicaemia. ${ }^{2-4}$ Disordered iron metabolism is probably the important common factor in those illnesses that predispose to yersinia septicaemia. ${ }^{5,6}$ We report a case of severe Yersinia pseudotuberculosis septicaemia in a man with hitherto undiagnosed haemochromatosis. A rare manifestation of haemochromatosis is aldosterone deficiency due to iron deposition in the zona glomerulosa of the adrenal cortex. ${ }^{7}$ We believe our patient has this complication which became manifest during the acute illness as polyuria, hyponatraemia and hyperkalaemia.

\section{Case report}

After 4 days holiday in Rhodes, a 50 year old Caucasian male developed a dull and constant lower abdominal ache, pain in both leg and arm muscles, headache, nausea, vomiting and fever. He was treated with unspecified intravenous antibiotics but following his return to England he continued with increasing nausea, intermittent fever, night sweats, shivering and complained of the recent onset of pleuritic chest pain.

Correspondence: S.P. Conway, M.A., M.B., B.S., M.R.C.P. Accepted: 21 July 1988
On examination he looked ill and icteric. His abdoment was generally tender but without guarding of rebound. An appendicectomy scar was evident. He mant a low grade temperature which peaked at 3कृष forty-eight hours after admission.

Three years previously, at another hospital, patient was found to have diabetes mellitus requiring insulin. Investigation for impotence 7 months after the onset of his diabetes had shown hypogonadotrophio hypogonadism with low plasma testosterone, follicle stimulating hormone and luteinising hormone levels $\frac{O}{3}$ A normal increment in plasma cortisol levels had been demonstrated in response to insulin-induced hypo glycaemia and thyroid function tests were normal.

Investigations on admission were as follows 3 . haemoglobin $13.3 \mathrm{~g} / \mathrm{dl}$, total white cell count $20 \times 10^{9} / 1$; $82 \%$ neutrophils, erythrocyte sedimentation rate $65 \mathrm{~mm} / \mathrm{h}$, bilirubin $20 \mu \mathrm{mol} / \mathrm{l}$, alkaline phosphatase 7 King Armstrong units, aspartate transaminase (AST) 109 units, alanine transaminase (ALT) 85 units음 albumin $28 \mathrm{~g} / \mathrm{l}$, globulin $45 \mathrm{~g} / \mathrm{l}$, plasma potassium $4.7 \mathrm{mmol} / \mathrm{l}$, sodium $127 \mathrm{mmol} / \mathrm{l}$, chloride $93 \mathrm{mmol} / \mathrm{l}$ 을. bicarbonate $29 \mathrm{mmol} / 1$, urea $6.8 \mathrm{mmol} / 1$, creating $88 \mu \mathrm{mol} / \mathrm{l}$, amylase 50.5 units. Chest X-ray showe right basal consolidation. Abdominal X-ray showed $\mathbb{R}^{2}$ moderate sized liver shadow. Treatment with eryth $\omega$ romycin was started for a possible atypical pneumonia. Two days after admission his clinicaf condition deteriorated. He remained febrile at $39^{\circ} \mathrm{C}$ with a markedly tender liver and abdomina $\tilde{L}_{\bar{b}}$ tenderness to very light palpation. Moderate diarro hoea was present with 13 loose stools in the first 4 days of admission. The illness was following a typhoid 
like' course and despite its rapid onset, only 4 days after his arrival in Rhodes, a diagnosis of typhoid fever was considered. A Widal test taken at this time (day 4) subsequently showed no evidence of Salmonella typhi or paratyphi infection.

Seven days after admission a Gram-negative bacillus was isolated after 48 hours incubation from one only out of several sets of blood cultures. This was identified as Yersinia pseudotuberculosis on the basis of its mobility at $22^{\circ} \mathrm{C}$ and lack of mobility at $37^{\circ} \mathrm{C}$ and by API. The latter is a standard identification system for Enterobacteriacae and other Gram-negative rods using a series of miniaturized biochemical tests and a data base. Subsequent serology from the national reference centre at Leicester Public Health Laboratory showed an antibody to type $1 \mathrm{~A}$ of 160 at 7 days, rising to 1280 by day 8 and falling to 640 by day 22 . Attempts at culture from faeces failed in spite of cold enrichment. Coincidental with the patient's improvement it was noticed that he was passing large volumes of dilute urine, specific gravity 1005-1010, with hyperkalaemia (highest $7.1 \mathrm{mmol} / \mathrm{l}$ ) and hyponatraemia (lowest $120 \mathrm{mmol} / \mathrm{l})$. Hyponatraemia had been present at admission and was considered to be a non-specific feature of severe illness. Blood glucose ranged from 4.4-13.3 $\mathrm{mmol} / 1$. The plasma and urinary electrolyte pattern suggested adrenal failure. A 5-hour depot tetracosactrin test was carried out and pending the results treatment with hydrocortisone and fludrocortisone was begun. The plasma potassium was $3.6 \mathrm{mmol} / \mathrm{l}$ and sodium $130 \mathrm{mmol} / \mathrm{l}$ on day 14 . The tetracosactrin test yielded normal base line plasma cortisol $(517 \mathrm{nmol} / \mathrm{l}$, reference range $200-750 \mathrm{nmol} / \mathrm{l})$ and an appropriate 5 hours response $(1171 \mathrm{nmol} / \mathrm{l})$.

On recovery from the acute yersinia infection investigations for haemochromatosis showed serum ferritin levels markedly elevated at 4550 and $4760 \mathrm{ng} /$ $\mathrm{ml}$ (male reference range 25-240). Liver biopsy showed massive accumulation of stainable iron in hepatocytes and Kuppfer cells. The portal tracts were expanded by fibrous tissue but there was no portalportal linking and the appearances fell short of cirrhosis. The patient was maintained on insulin and $200 \mu \mathrm{g} /$ day of fludrocortisone and some weeks after recovery, adrenal function was investigated. Basal plasma cortisol was $390 \mathrm{nmol} / 1$ and increased to $1360 \mathrm{nmol} / \mathrm{l}$ five hours after $1 \mathrm{mg}$ depot tetracosactrin intramuscularly, a normal response. Having discontinued the fludrocortisone for 6 days, an angiotensin infusion test $^{8}$ was carried out and showed no significant increment in plasma aldosterone above the basal level in response to angiotensin (Table I).

\section{Discussion}

Yersinia septicaemia may present as a subacute localized form with hepatosplenic abscesses or follow
Table I Plasma aldosterone response to infusion of angiotensin II $5 \mathrm{ng} / \mathrm{kg} / \mathrm{min}$

\begin{tabular}{cc}
\hline $\begin{array}{l}\text { Time } \\
\text { (minutes) }\end{array}$ & $\begin{array}{c}\text { Plasma aldosterone* } \\
\text { (pmol/l) }\end{array}$ \\
\hline 0 & $440 / 500$ \\
30 & 320 \\
60 & 440 \\
90 & 390 \\
120 & 470 \\
150 & 320 \\
\hline
\end{tabular}

* Reference range after overnight recumbency, $100-500 \mathrm{pmol} / \mathrm{l}$.

a 'typhoidal course' with a rapid rise in temperature, rigors, abdominal, joint and limb pain, hepatosplenomegaly, exudation in serous cavities and a continuing or intermittent temperature. ${ }^{9,10}$ The association between yersinia septicaemia and pre-existing liver disease is well recognized. ${ }^{11,12}$ In our patient the diagnosis of haemochromatosis was established by the markedly elevated serum ferritin level and the liver biopsy findings. This diagnosis accorded with the previous history of diabetes mellitus and hypogonadotrophic hypogonadism. It has been theoretically argued that bypassing of the hepatic reticuloendothelial filtering mechanism in chronic liver disease allows the bacteraemia. ${ }^{13}$ Iron overload is, however, the probable common factor linking those illnesses that predispose to severe yersinia infection. ${ }^{4,9,14-16}$ Iron is an essential bacterial growth factor, and animal experiments have shown increased virulence and a decreased $\mathbf{L D}_{50}$ in an iron-stressed host. ${ }^{17,18}$ Most aerobic and facultative anaerobic bacteria are able to synthesize siderophores in response to a low availability of iron in their environment. These 'iron-bearers', low molecular weight ligands, are released from the cell, compete with the host iron binding proteins for available iron, and are taken up by membrane specific receptors as ferric chelates before releasing their iron to the cell. ${ }^{19}$

Although $Y$. pseudotuberculosis and $Y$. enterocolitica grow rapidly in a defined iron sufficient medium, they fail to release detectable siderophore activity in an iron-deficient medium..$^{20}$ Both of these organisms can use common exogenous siderophores produced by other micro-organisms and are therefore able to thrive in the gut. Body iron is, however, mostly bound in the form of haemoglobin or ferritin. In conditions associated with iron overload, with saturation of serum transferrin, the pool of iron is bound non-specifically to other proteins and is more available to bacteria. ${ }^{21}$ This more ready supply of iron will encourage yersinia septicaemia. ${ }^{5}$

Our patient exhibited classic features of $Y$. pseudotuberculosis septicaemia with pre-existing 
haemochromatosis and diabetes mellitus, a typhoidallike illness with marked abdominal tenderness, full recovery with intensive and early treatment with appropriate antibiotics, and isolation of type 1A, responsible for the large majority of human infections. ${ }^{1}$ The predilection for iron to be deposited in the zona glomerulosa has long been known. ${ }^{22}$ Only recently, however, has aldosterone deficiency causing a clinical problem been described. ${ }^{7}$ In our patient the water, sodium and potassium derangement were compatible with adrenocortical hypofunction but normal glucocorticoid release from the adrenal was demonstrated. However, although the basal plasma aldosterone level was in the normal range, indeed at

\section{References}

1. Mair, N.S. Sources and serological classification of 177 strains of Pasteurella pseudotuberculosis isolated in Great Britain. J Pathol 1965, 90: 275-278.

2. Hnatko, S.I. \& Rodin, A.E. Pasteurella pseudotuberculosis infection in man. Can Med Assoc J 1963, 88: $1108-1112$.

3. Blattner, R.J. Acute mesenteric lymphadenitis. J Pediatr 1969, 74: 479-481.

4. Bradley, J.M. \& Skinner, J.I. Isolation of Yersinia pseudotuberculosis serotype $\mathrm{V}$ from the blood of a patient with sickle-cell anaemia. J Med Microbiol 1974, 7: 383-386.

5. Anon. Yersiniosis today. Lancet 1984, i: 84-85.

6. Gordts, B., Rummens, E., DeMeirleir, L. \& Butzler, J.P. Yersinia pseudotuberculosis septicaemia in thalassaemia major. Lancet 1984, i: 41-42.

7. Thomas, J.P. Aldosterone deficiency in a patient with idiopathic haemochromatosis. Clin Endocrinol 1984, 21: $271-277$.

8. Brown, J.J., Chiu, R.H., Fraser, R. et al. Recurrent hyperkalaemia due to selective aldosterone deficiency: Correction by angiotensin infusion. $\mathrm{Br} M e d J$ 1973, 1: 650-654.

9. Rabson, A.R., Hallett, A.F. \& Ksornhoff, H.J. Generalised Yersinia enterocolitica infection. J Infect Dis 1975, 131: 447-451.

10. Knapp, W. Mesenteric adenitis due to Pasteurella pseudotuberculosis in young people. $N$ Engl J Med 1958, 259: 776-778.

11. Marlon, A. \& Merigan, T.C. Septicaemia with Pasteurella pseudotuberculosis and liver disease. Arch Intern Med 1971, 127: 947-949. the upper end, it did not increment as it should have done in response to angiotensin infusion. We concludę that although aldosterone production was adequate for unstressed life, the demands of the very sever尺 illness could not be met. This resulted in considerable. loss of sodium and water, and potassium retention.

\section{Acknowledgements}

We thank Dr J. Stevenson for encouragement and advice and for allowing us to report this case.

12. Yamashiro, K., Goldman, R.H., Harris, D. \&. Uyeda, C.T. Pasteurella pseudotuberculosis. Acute sepsis with survival. Arch Intern Med 1971, 128: 605-608.

13. Conn, H.O. Spontaneous peritonitis and bacteraemia in $\downarrow$ Laennec's cirrhosis caused by enteric organisms. Anne Intern Med 1964, 60: 568-580.

14. Butzler, J.P., Alexander, M., Segers, A., Cremer, N. \&zz Blum, D. Enteritis, abscess, and septicaemia due to Yersinia enterocolitica in a child with thalassaemia. $\mathcal{S}$ Pediatr 1978, 93: 619-621.

15. Melby, K., Slordahl, S., Gutteberg, T.J. \& Nordbo, J㣽. Septicaemia due to Yersinia enterocolitica after ofal overdoses of iron. $\mathrm{Br}$ Med J 1982, 285: 467-468.

16. Bouza, E., Dominguez, A., Meseguer, M. et al. Yersinita enterocolitica septicaemia. Am J Clin Pathol 1980, 74: 404-409.

17. Weinberg, E.D. Iron and infection. Microbiol Rev $1978 \stackrel{\circ}{\overparen{D}}$ 42: $45-66$

18. Bullen, J.J. \& Rogers, H.J. Bacterial iron metabolism응 and immunity to Pasteurella septica and Escherichia coli. Nature 1969, 224: 380-382.

19. Neilands, J.B. Microbial iron compounds. Ann Rev Biochem 1981, 50: 715-731.

20. Perry, R.D. \& Brubaker, R.R. Accumulation of iron by Yersiniae. J Bacteriol 1979, 137: 1290-1298.

21. Brock, J.H. Iron and the outcome of infection. Br Med 1986, 293: 518-519.

22. Sheldon, J.H. Haemochromatosis. Oxford University Press, London, 1935. 